\title{
Jazzing a Classic: Hylton and Stravinsky's Mavra at the Paris Opéra
}

\section{DEBORAH MAWER}

\begin{abstract}
This article focuses upon an arrangement of part of Stravinsky's Mavra made for the British dance-band leader Jack Hylton (1892-1965), which, on its presentation at the Paris Opéra in 1931, marked a notable, yet ultimately unsuccessful, attempt at 'jazzing a classic'. For the French critic Pierre Leroi the failure was a direct consequence of combining different musics ('La confusion de genres aboutit toujours à un résultat mauvais'). But while the 'contest' of style and genre undoubtedly played its part in the negative critical reception of the transcription, the reasons for its failure were not entirely straightforward.

Drawing on Fauconnier and Turner's models of 'conceptual blending' and their recent applications in theories of musical 'multimedia', I compare Stravinsky's source and the Hylton band's jazz translation in terms of their intrinsic musical 'attributes', their relationship, and their potential emergent meanings. The exercise identifies commonalities and discrepancies, revealing problems with the original, the reworkings, and the resulting performances. The main issue is, however, not so much one of mixture ('confusion') as of imbalance between the elements invoked: ultimately, it is argued, Hylton's reading was insufficiently 'jazzique'.
\end{abstract}

On 17 February 1931, upon the hallowed ground of the Opéra, the British dance-band leader and entrepreneur Jack Hylton (1892-1965) directed an arrangement of a portion of Stravinsky's Mavra - a bold attempt at 'jazzing a classic', which nonetheless met with a broadly negative critical reception. For the French critic Pierre Leroi, the failure of the venture was a direct consequence of combining different musics: 'The mixing up of genres always leads to a bad result.' ${ }^{1}$ Some nine years earlier Boris de Schloezer had pronounced very similarly upon Stravinsky's original Mavra, which itself received its première at the Opéra: 'the two styles Italo-Russian and black American - never succeed in meshing but only impede one another'. ${ }^{2}$

This article was presented in an earlier version as an invited seminar at the Institute of Musical Research, University of London, October 2007, and has benefited from feedback from Katharine Ellis, Nigel Simeone, Andy Fry, and others. The article emerges from a research project, 'Jack Hylton and France', undertaken in spring 2007 at the Jack Hylton Archive (JHA), Lancaster University. It is a sister article to Deborah Mawer, "Parisomania"? Jack Hylton and the French Connection', Journal of the Royal Musical Association 133/2 (2008), 270-317, which identifies the discrete topic of 'Hylton, Stravinsky and the Opéra' (293-8) and makes mention of this complementary and more detailed study (295n). I am grateful for funding from Lancaster University and PALATINE, for the support of Helen Clish at Lancaster's Rare Books Archive (which houses the Hylton collection), and for the excellent contribution of my research assistant, Adam Greig. I am also appreciative of Peter Faint's groundwork in his 1998 dissertation 'Jack Hylton: His Life in Music'.

1 Leroi, 'Jack Hylton à l'Opéra'.

2 Boris de Schloezer, 'La musique', Nouvelle revue française 9/106 (1 July 1922), 118 (quoted in Taruskin, Stravinsky and the Russian Traditions, vol. 2, p. 1597). 
This article looks to probe these relations: while the problems involved in 'jazzing' a piece of classical music - problems that engage the closely entwined notions of style and genre - are central to this inquiry, the reason for the failure of the Hylton-Stravinsky venture is, I shall argue, not as straightforward as Leroi claimed. By means of Fauconnier and Turner's model of conceptual blending, combined with an approach theorized broadly after Nicholas Cook's analyses of musical multimedia, ${ }^{3}$ I shall compare the Stravinsky 'source' and Hylton's subsequent dance-/jazz-band translations in terms of their intrinsic musical 'attributes', relationships, and potential emergent meanings, with the ultimate aim of discovering why the 'jazzed' concept failed in this case. Although this inquiry is predominantly analytical, it also impinges upon, and therefore addresses, historical and wider socio-cultural considerations. My primary intention is not to reconstruct the authorial intent of Stravinsky or Hylton (though poietic matters are considered en route), but to engage in a hermeneutic (esthesic) reading. ${ }^{4}$

Around 1930 Hylton was at the height of his career - one that flourished in France and would be acknowledged in January 1932 by the award of an officership in the Légion d'honneur. ${ }^{5}$ In June 1930 he had enjoyed tremendous success at the Salle Pleyel in Paris, while another performance of 'Jack Hylton et ses "boys"' at the Théâtre des Champs-Elysées had been applauded by one of the grand old men of French criticism: in an issue of Excelsior dated 7 April 1930 Emile Vuillermoz offered a review brimming with superlatives, in which he described the band as 'this company of virtuosos', whose 'two concerts were two evenings of apotheosis'. 'Here we have first-rate musical parody', he concluded. ${ }^{6}$ This valuable publicity was reprinted in Hylton's programme for the Opéra.

But despite all this, and despite a generally very successful show on 17 February 1931, the advertised highlight ${ }^{7}$ - a special arrangement of an extract from Stravinsky's one-act opera buffa Mavra - was almost universally dismissed as a failure. According to the usually generous Vuillermoz, it was a 'total failure' and one that was 'perfectly deserved' ('un échec total [... ] parfaitement mérité'). ${ }^{8}$ Such a damning verdict, even had it been isolated, would warrant critical investigation. But before a detailed analysis is undertaken, it makes sense to outline the context of this notable instance of 'cross-over', the genesis of the arrangement (and, indeed, of its two surviving versions), and the methodological basis of this study.

3 Fauconnier and Turner, The Way We Think; Cook, Analysing Musical Multimedia. For further details on the critical approach adopted in this study, see section III below.

4 On basic poietic/esthesic distinctions and interplay see Nattiez, Music and Discourse.

5 According to Hylton's son, also named Jack, this award was 'mostly as a result of the Paris Opera [and other] concerts - the proceeds of which benefited the French Red Cross' (personal communication, 10 October 2008). For a comprehensive introduction to Hylton in France see Mawer, "'Parisomania"?'.

6 Vuillermoz, 'La musique: Jack Hylton et ses "boys"'.

7 See [writer unknown] 'Stravinsky et Jack Hylton', or the preview of the event published in Le temps, 17 February 1931. Missing author credits are, unfortunately, a recurrent issue in the JHA. The various volumes of Jack Hylton [Press] Cuttings were created for contemporary publicity rather than future academic purposes.

8 Vuillermoz, 'La musique, les concerts'. 


\section{I 'Jazz'-classical context}

Early jazz is very slippery to define: in the 1920s it denoted a range of styles and repertories. Even within Europe it meant different things to the likes of Stravinsky and Hylton, and even to Hylton himself: his early self-distancing from jazz may be contrasted with his warmer embrace of it around 1930, which mirrored that of his public. ${ }^{9}$ Meanwhile the notion of 'jazzing' the classics, through arrangements and reworkings of classical pieces and, by extension, the borrowing of classical music styles and textures, goes right back to the early days of ragtime, with stride pianists who were frequently classically trained. ${ }^{10}$

Allusion to classical works and idioms was employed within early jazz and popular music for varied purposes, ranging from associative cachet to lampooning for comical or satirical ends. The sophisticated compositions of Duke Ellington (1899-1974) offer an eloquent synthesis of styles, ${ }^{11}$ while Paul Whiteman (1890-1967) walked the ultimate tightrope with the commissioning of Gershwin's Rhapsody in Blue and its première in 1924, with the composer at the piano. (The scoring of the Rhapsody was undertaken by Whiteman's orchestrator, Ferde Grofé.) In Britain the bandleader Jack Payne (1899-1969), director of the BBC Dance Orchestra, had a best-selling rendition of Ravel's Boléro on the Columbia label. And, where Hylton and his band were concerned, the jazzing of generally light classics took as its objects such pieces as Rachmaninov's Preludes in G and C sharp minor (produced by his arranger Peter Yorke) in 1930; Cécile Chaminade's 'Pas des écharpes', recorded in 1925; Jules Massenet's 'Méditation' from Thaïs; Gershwin's Rhapsody itself; and one of the shortest versions ever undertaken of Ravel's Boléro, arranged in 1936 by Hylton's second-incommand, William Ternent (1899-1977).

Equally, a number of early twentieth-century modernist composers, especially those active in France, such as Milhaud, Auric, Ravel, and Stravinsky, invoked and adapted ragtime, blues, and jazz to their own artistic ends. Notwithstanding Gershwin's background in American popular music, his more classically oriented Piano Concerto in F of 1925, which he orchestrated himself, arguably belongs also to this category. While Stravinsky's activities need little introduction or contextualizing, the products of his enthusiastic engagement with ragtime, catalysed by sheet music brought to him by Ernest Ansermet during his wartime exile in Switzerland, may at least be listed: the 'Ragtime' from L'histoire du soldat (1918), Ragtime for eleven instruments (1918), Three Pieces for clarinet solo (1918), Piano-RagMusic (1919), and later, in America, the Ebony Concerto (1945) for Woody Herman.

Intriguingly, just a fortnight after Hylton's performance of Mavra, Stravinsky was apparently already involved in another venture to rethink his music for popular tastes. On 2 March 1931 he wrote to the publisher F. V. Weber concerning a suite version of Petrushka, lasting

9 On fluid definitions of early jazz see Jackson, Making Jazz French. The rough chronology of Hylton's changing views can be gauged from the titles of various articles he wrote in the course of less than a decade, from "JJazz Only in its Infancy”' (1927) through 'Naissance et vie du jazz' (1932) to 'Jazz! The Music of the People' (1934).

10 See Cooke, 'Jazz Among the Classics'. For more detailed coverage of relationships between jazz, classical, and popular music see Mawer, “Parisomania”?', 280-84.

11 On such blending see, for instance, the chapter 'Black and White: Quotations in Duke Ellington's “Black and Tan Fantasy"' in Metzer, Quotation and Cultural Meaning, 47-68. 
about twenty minutes and comprising 'Hocus-pocus' and 'Russian dance', in addition to Scenes 2 and $4 .{ }^{12}$ On 15 February 1932, almost exactly a year after the Opéra performance, he contacted his publisher Païchadze, demanding impatiently, 'When is Petrushka finally going to be published for popular orchestra?'. Robert Craft believes this question to refer to a 'jazz-band arrangement of certain sections, similar to the arrangement of Mavra'. ${ }^{13}$ Where the repackaging of parts of Mavra itself was concerned, a few years later in 1937 Stravinsky sanctioned a version of Parasha's folk-like initial aria - the 'Chanson russe', first extracted as an independent concert number in 1923 - arranged by the violinist Samuel Dushkin.

On its presentation at the Opéra in February 1931 the Hylton band's arrangement of Mavra was presented as the high spot of the programme, near the start of the second half. The first half comprised the standard, light-hearted dance-band repertory: predominantly 'sweet' numbers that were guaranteed to go down well with the audience, including Chevalier's song 'You Brought a New Kind of Love' and the spiritual 'Swing You Sinners', interspersed with a judicious number of 'hot' items: Ternent's arrangement of 'Limehouse Blues', the iconic 'Saint-Louis Blues', and standards such as 'Ain't Misbehavin" and 'Tiger Rag'.

\section{Historical and conceptual genesis of the Mavra arrangement(s)}

The impetus for a 'jazzed' version of one of his compositions seems to have come from Stravinsky, who was apparently attracted by hearing Hylton's band. ${ }^{14}$ Subsequently, according to Hylton's testimony in The Daily Sketch, 'Stravinsky sent for me while I was in France and offered to write a composition we could play. He [...] interviewed each of my men to get the right angle on his music.' ${ }^{15}$ These discussions seem to have taken place in Paris in mid-May 1930, towards the end of one of Hylton's European tours, the timing corroborated by the date of Stravinsky's inscription on a copy of the published vocal score of Mavra, later sent to Hylton: 'Pour Monsieur Jacques Hylton en bon souvenir. Igor Strawinsky, Paris, le 17

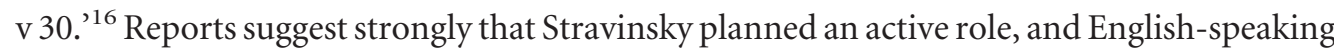
press coverage about a 'collaboration' supported Hylton's interpretation that newly composed music would be involved: 'Igor Stravinsky, modernistic composer, is going jazzique in collaboration with Jack Hylton's band. ${ }^{\prime 17}$ The French press too reported that the composer

12 Craft (ed.), Stravinsky: Selected Correspondence, vol. 1, pp. 396n-397n.

13 Craft (ed.), Stravinsky: Selected Correspondence, vol. 1, p. 397n. In Stephen Walsh's judgement, however, 'that Petrushka reference is isolated and speculative. It might obviously refer to Hylton in which case the possibility will have been raised when they met in 1931. But I can't locate any previous mention of it in the Païchadze correspondence [housed at the Paul Sacher Stiftung, Basel] [...] so any discussion must have been in conversation.' (Personal communication, 24 November 2008).

14 For an initial outline see Mawer, “"Parisomania”?', 295-6.

15 [Writer unknown], 'Jack Hylton's 9,000 Mile Tour'. See a similar account in The Voice (August 1930), quoted in Taruskin, Stravinsky and the Russian Traditions, vol. 2, p. 1569n.

16 The score is held in the Jack Hylton Archive (hereafter JHA).

17 [Writer unknown], 'Jack Hylton's Jazz Guiding Stravinsky'. 
was to embark on 'a specially conceived work' ('une oeuvre spécialement conçue'), to be premièred by Hylton. ${ }^{18}$

On 10 September 1930 Hylton wrote to Stravinsky, asking when they might meet to 'discuss the music which you honoured me by asking me to play' ${ }^{19}$ But, sadly for posterity, the prospect of a collaborative compositional opportunity quickly faded to a simple granting of permission to Hylton for the rearrangement of part of Mavra - thus inverting the compliment and undermining the original creative purpose. It was even claimed that Hylton had initiated the idea and selected the intended sections ${ }^{20}$ - an improbable suggestion, given his unfamiliarity with Stravinsky's style and score. Conversely, Craft, implicitly disparaging of Hylton, assumed that ' $[\mathrm{n}] \mathrm{o}$ doubt Stravinsky reworked the arrangement', ${ }^{21}$ but there is no evidence to support this. Stravinsky did admit to listening to Hylton's rendition in the Small Queen's Hall studio in London, 'so that the arrangement would conform to the original version of the work'. ${ }^{22}$ (Interestingly, this statement implies that he did not envisage an arrangement entailing any alteration of the work-concept or meaning of the original, a point that will be explored below; suffice it to say that the arrangement did not conform in all respects.) Stravinsky's ultimate act of estrangement was the disingenuous and supercilious tone he adopted in seeking to minimize his involvement in the enterprise that he had initiated: 'Mr Hylton actually conducted this Mavra potpourri at the Paris Opera(!) in 1932 (I believe). ${ }^{23}$ The feigning of ignorance is contradicted by Stravinsky's presence in the audience. Bizarrely, given his admission of jazz influence on the same page of Expositions and Developments, he concluded that 'Mavra has no place on a "jazz" programme'.

The choice of Mavra for transcription was a puzzling one for reasons that will become increasingly apparent (the original Mavra too created puzzlement, for instance, as a nonballet for the Ballets russes). ${ }^{24}$ Stravinsky may have been distracted by his Symphony of Psalms and Concerto in $\mathrm{D}$, or, as the press intimated, may have found creating a new jazz work, or even an arrangement, more difficult than he had imagined: 'That the arrangement was no easy matter is indicated by the fact that Stravinsky, who knows more about tone colour and balance than probably any other man alive, was unwilling to undertake the task himself.' ${ }^{25}$ But once Stravinsky was committed to providing something and perhaps, as Peter Faint has suggested, had sensed 'a way to [...] become better known amongst the public', ${ }^{26}$ he may have seen as the readiest way of achieving this objective the recycling of a work - and one

18 See article in Semaine musicale, 30 May 1930.

19 Hylton, quoted in Craft (ed.), Stravinsky: Selected Correspondence, vol. 2, p. 123n.

20 Craft (ed.), Stravinsky: Selected Correspondence, vol. 2, p. 123n. The sections are indicated in pencil on the vocal score signed by Stravinsky and are also marked on the orchestral score: see Example $1 \mathrm{~b}$.

21 Craft (ed.), Stravinsky: Selected Correspondence, vol. 2, p. $124 \mathrm{n}$.

22 Craft (ed.), Stravinsky: Selected Correspondence, vol. 2, p. 123n. The arrangement was not actually recorded. For more on the rehearsals, Stravinsky's attendance, and the subsequent performance see Peter Faint's website: <http:// www.petefaint.co.uk/jackhylton/STRAV.HTM > (accessed 1 May 2009).

23 Stravinsky and Craft, Expositions and Developments, 82n.

24 See Taruskin, Stravinsky and the Russian Traditions, vol. 2, pp. 1538-9.

25 Lucas, 'Jack Hylton and Stravinsky: a Jazz Symphony'.

26 See again Peter Faint's website: <http://www.petefaint.co.uk/jackhylton/STRAV.HTM>. 
already possessing certain jazz credentials - that had not quite received its due. Stravinsky had been most upset at the reception the work was given at its première: 'Mavra was regarded as a disconcerting freak of mine [...]. Only a few musicians of the younger generation appreciated Mavra. ${ }^{27}$ Thus he may well have wanted to give it another chance to prove its worth, even though he had by December 1923 witnessed a successful concert performance, conducted by Ernest Ansermet in the Concerts Wiéner series. ${ }^{28}$

\section{Critical approach}

To support the focus of the article I have invoked flexibly the central apparatus of 'conceptual blending', developed by Gilles Fauconnier and Mark Turner, ${ }^{29}$ which Nicholas Cook and Lawrence Zbikowski, among others, have applied to music. ${ }^{30}$ The essential principle is illustrated attractively by Zbikowski, who refers to A. A. Milne's character Eeyore in terms of two (mental, metaphorical) input spaces: 'donkey' and 'human', the correlating elements of which are then mapped (in the process described as 'running the blend') onto a 'blended' space; this process results in 'Eeyore' as a 'talking donkey'. ${ }^{31}$ Cook uses such conceptual integration networks (CINs) to mediate between music and film or text spaces in his quest to probe intra- and extra-musical meanings. ${ }^{32}$ For two entities to be related, they need to exhibit some measure of 'enabling similarity', so that the researcher may then explore a " "blended space" in which attributes unique to each medium are combined, resulting in the emergence of a new meaning' ${ }^{33}$

Implicit here is the idea of multimedia, whether involving music in combination with a completely different medium, such as text or dance, or, as here, the co-existence of distinct genres or types of music: different musics. Indeed, in his book Analysing Musical Multimedia, Cook has discussed 'similarity' and 'difference' tests ${ }^{34}$ as an extension of the work of George Lakoff and Mark Johnson. ${ }^{35}$ 'Consistent' expressions of similarity may result in 'conformance', while more divergent, yet still 'coherent', expressions may lead to a state of difference; in turn, difference may result in complementation or actual 'contest'. While 'Conformance begins with originary meaning [.. .] contest, on the other hand, ends in meaning', ${ }^{36}$ and thus can yield the greatest scope.

A useful supplement to these models is the simpler and less rigorously theorized approach of Daniel Albright, who considers relationships between music and other arts in terms of

27 Stravinsky, An Autobiography, 103.

28 Stravinsky, An Autobiography, 110.

29 For a comprehensive exposition see Fauconnier and Turner, The Way We Think.

30 See Cook, 'Theorizing Musical Meaning', and Zbikowski, Conceptualizing Music.

31 Zbikowski, Conceptualizing Music, 77-9.

32 Cook, 'Theorizing Musical Meaning', 183-5.

33 Cook, 'Theorizing Musical Meaning', 181.

34 Cook, Analysing Musical Multimedia, 98-106, diagram 99.

35 Lakoff and Johnson, Metaphors We Live By.

36 Cook, Analysing Musical Multimedia, 103. 
aesthetic 'consonance' and 'dissonance'. Rather than conceiving 'the mixed arts' as a counterpoint between independent artistic media, he considers those moments of 'transmediation' in which the 'deep concord' between the different sensory aspects of a multimedia experience means that 'all consciousness of the constituent arts vanishes' ${ }^{37}$ These 'transmediating chords [...] vibrat[e] between media, abolishing the distinctness of media'. ${ }^{38}$ But consonance is just one aspect of this 'vertical', 'harmonic' dimension. For Albright, like Cook, 'divergence' - or what he calls 'dissonance' - offers if anything greater creative potential, resisting straightforwardly mimetic relationships in a way that causes 'the impression of realness, thereness, [to be] heightened, not diminished'. Albright sees in many multimedia artworks a layering of consonant and dissonant relations, mooting a 'law of conservation of dissonance', such that 'when the music is dissonant, then the relations [...] between music and painting or poetry tend to be consonant, and vice versa' ${ }^{39}$ For instance, in Le sacre du printemps (which he discusses in detail), Stravinsky's 'dissonant' music is in a close, 'consonant' relationship with Nijinsky's (internally 'dissonant') choreography. Con-

versely, predominantly 'consonant' music needs a more challenging, 'dissonant' relationship with a companion art-form to avoid predictability and create a strong partnership. In combining aspects of Cook and Albright my approach resembles that which I have previously adopted in mediating music, dance, and meaning in Ravel, embracing the cultural as much as the cognitive. ${ }^{40}$ And here too there is potential for the creation of additional emergent meanings or implications as a consequence of the blending - the notion of the whole as somehow greater than the sum of its parts - albeit not the creation of a new (multimedia) artwork as such. In this case both the original work and the arrangement(s) retain a separate existence, notwithstanding the inevitable dependence of the latter on the former.

From this point on the reader is advised to refer to the orchestral score of Stravinsky's Mavra $^{41}$ to facilitate comparison with the final manuscript arrangement by Ternent.

\section{Identities, relations and emergent meanings}

Figure 1 provides a basic map which acts as a point of reference throughout the analysis, charting a number of attributes (such as jazz or orchestral sound, opera or non-opera) within and across various categories (such as orchestration or genre). At the top left of the figure, I position Stravinsky's concept of Mavra, in the form in which it was premièred on 3 June 1922, as a predominantly (neo)classical entity - as much a commentary on popular opera

37 Albright, Untwisting the Serpent, 5-7, 12, 29.

38 Albright, Untwisting the Serpent, 5-6.

39 Albright, Untwisting the Serpent, 29.

40 See Mawer, 'Balanchine's La valse'.

41 Igor Stravinsky, Mavra (Berlin and London: Edition Russe de Musique, 1925; rev. edition Boosey \& Hawkes, 1947; English edition, full score, 1969). When music references in the text are related to score rehearsal figures, please note the following shorthand: Fig. $1^{-2}$ indicates the second bar preceding Fig. 1; Fig $1^{+2}$ indicates the second complete bar of Fig. 1. 
past, which it seeks to reinvigorate, as a work on its own terms. This, the 'original' Mavra, offers, as Stephen Walsh notes, 'a neat and affectionate parody' of nineteenth-century models, relating musically to Glinka and Tchaikovsky, and, in Boris Kochno's libretto, to the oeuvre of Pushkin, specifically The Little House in Kolomna. ${ }^{42}$ (The score is dedicated to the memory of these three figures.) The use of a restricted plot for just four characters - Parasha, her Mother, the Neighbour, and the Hussar (alias Cook, 'Mavra') - is another salient feature.

\section{Notion of Mavra}

Stravinsky original (Medium/input 1)

Mavra as a 'classical' artwork

(opera premièred 1922)
Hylton: Ternent/Lucas (Medium 2)

Mavra as two 'jazz'/popular

arrangements (Ternent premièred 1931)

\section{Interaction (A): Cook, 'conformance' (Albright, 'consonance')}

1 Substantial common element to the instrumentations

2 Common pitch-time frame (Figs 44-92)

3 Difficult to realize in performance (both at the Opéra)

\section{Interaction (B): Cook, 'complementation'-'contest' (Albright, 'dissonance')}

1 Stravinsky sound: orchestral scoring, with some 'jazz' influence, even if 'very alien corn'

2 Opera buffa; an attempt at a lighter work (yet complex, esoteric, ironic); narrative, dramatic, and historicized meanings

3 Neoclassical foundation: vocal and instrumental

One full act
Hyltonized dance-band sound: some 'jazz' gestures, plus symphonic tendencies (especially Lucas)

Neither opera, nor buffa: an attempt to be taken seriously; suppression of narrative, or intended dramatic meaning

Heightened (neo)classicism: instrumentalized reading: Pulcinella-like; Lucas version: 'Suite'; 'disembodiment' of singers; Six-minute extract 'detached' (plus Lucas's extra portion): possible metonym; (non-)ending in the middle

\section{Emergent blend/potential meaning \\ Orchestral/dance-band sound Opera/non-opera Overarching neoclassicism}

Figure 1 Relations between Stravinsky's Mavra and Hylton's dance-band version (classical 'jazz'/popular blending). 
At the top right of Figure 1 are positioned the two 'jazz'/popular versions of Mavra undertaken by Hylton's arrangers, Leighton Lucas (1903-82) and Ternent, which are preserved as black-ink dance-band manuscripts. ${ }^{43}$ The first attempt by Lucas, based on two portions of the score (Figs 44-92 and 97-112), was stylistically much closer to Stravinsky than the later arrangement and was deemed too symphonic; Lucas's score was then simplified and emboldened by Ternent in order to conform to the typically full sound of Hylton's band. This second version, limited to Figs 44-92, represents what was heard at the Opéra.

While conjectural, a plausible reasoning behind the selection of these extracts for arrangement might run as follows: the main extract begins at the lively 'Tempo giusto' with what is known as the 'Gossip Duet' (Figs 44-68) between Mother and the Neighbour, a section which Richard Taruskin has viewed as operating within Stravinsky's lighter mode, imbued with his 'polka-party geniality'. ${ }^{44}$ The light, bantering style in regular $2 / 4$ metre makes this a suitable self-contained unit for further 'jazzed' treatment: its opening exchange of mundane pleasantries about the weather presents an art of the everyday, consistent with Hylton's own pragmatic stance. (Although the two characters enter at Fig. 43, the frequent metrical irregularity would have rendered this an inappropriate opening.)

Beyond Fig. 68, marked by Parasha's appearance and set generally in common time, most of this section comprises the 'Quartet' (Fig. 75ff), a rich climactic passage in which all four characters are featured against an um-cha-cha-type accompaniment. Indeed, Stravinsky noted of his original that 'there was a certain jazz element in it - the quartet especially - that seemed to require a "band" sound rather than an "orchestral" sound'. ${ }^{45}$ Thus this portion, ending just before the change to 6/8 at Fig. 93, would have been a logical choice for the dance-band arranger. The additional section (Figs 97-112, treated only by Lucas) picks up at the 'Con moto', in regular 2/4 metre, with the lovers' duet between Parasha and the Hussar, climaxing at the caesura before Fig. 108, though the abrupt ending of the arrangement at the third bar of Fig. 112 does not coincide with any natural break within Stravinsky's music.

In relation to the rest of the work these extracts - with their metrical regularity and a certain degree of melodic appeal - represent some of the most 'accessible' music from the perspective of both an audience and the band performers. In dramatic terms, for those familiar with the drama, they balance the two manifestations of the central character: the Hussar in disguise (as Mavra the female cook) and the Hussar as himself, prefiguring the (melo-)dramatic revelation of his true identity to the girl's Mother when he is caught shaving (Fig. 163ff; Coda).

\section{A Stravinsky and Hylton: 'conformance'}

A first set of interactions between Stravinsky's original and Hylton's arrangements, grouped as Interaction (A) in Figure 1, exhibits a high degree of Cook's 'conformance', or Albright's 'consonance'. ${ }^{46}$ Both here and in Interaction (B) below I have isolated a number of attributes

43 JHA, 599.

44 Taruskin, Stravinsky and the Russian Traditions, vol. 2, p. 1569.

45 Stravinsky and Craft, Expositions and Developments, 82.

46 See Cook, Analysing Musical Multimedia, 99ff, and Albright, Untwisting the Serpent, $6 \mathrm{ff}$. 
pertaining to instrumentation, pitch-time frame, orchestration, style, genre, and performance, as a way of seeking to clarify identities, relationships, and, in due course, meanings. This is an interpretative act on my part and cannot be deemed absolute or fixed. In a similar spirit, the suggested categories are not exclusive; inevitably there are both overlaps and gaps. This approach nonetheless offers a framework from which developments or deviations can be enacted.

Table 1 Comparison of instrumentation for Stravinsky's Mavra (1922) and arrangements by Lucas and Ternent (1931).

\begin{tabular}{lll}
\hline Stravinsky & Lucas & Ternent \\
Parasha & - & - \\
Neighbour & - & - \\
Mother & - & - \\
Cook (Mavra) & - & - \\
Picc., 2 Fls & Fl. & Fl. \\
2 Obs, C.a. & Ob. & - \\
Eb Cl., 2 Cls (Bb, A) & - & 2 Cls \\
2 Bns & - & - \\
2 Vns, Vla & 3 Vns & 3 Vns \\
4 Hns & 2 Saxes (Alto, Tenor) & 3 Saxes (Alto) \\
4 Tpts (C, A) & 2 Tpts & 2 Tpts \\
2 Tbns (Tenor) & 2 Tbns (Tenor) & 2 Tbns, Sax. (Tenor) \\
Tbn. (Bass) & Sax. (Baritone) & Sax. (Baritone) \\
Tuba & - & - \\
Timp. & Drums & Timp., Drums \\
- & Xyl. & Xyl. \\
Pno [vocal score] & Pno & Pno [vocal score] \\
Vlc. & Vlc. & Vlc. \\
Cb. & Cb. & Cb. \\
\hline
\end{tabular}

Firstly, a comparison of the instrumentation of Stravinsky's original and the arrangements (especially that of Ternent) reveals substantial commonality; for a comparative listing see Table 1. From the start Stravinsky had utilized an atypical orchestral score layout influenced by jazz-band style, divided functionally into melody and rhythm-bass sections. Notably, the violin and viola lines are positioned above horns, trumpets, trombones, and tuba, spatially separated from the cello and bass. Stravinsky's instrumentation favoured woodwind and brass: 'I used wind instruments principally, both because the music seemed to whistle as wind instruments whistle' and (to return to the comment quoted above) because of 'a certain jazz element', which signalled a 'band' sonority. ${ }^{47}$ The nature of the resulting sounds will be 
considered later in terms of its specific qualities of orchestration, but the point to be noted here is that Stravinsky had at least partially anticipated and exploited the jazz-/dance-band instrumentation, so leaving less scope for significant rethinking by Hylton's musicians.

Examples 1 (Figs 44-5) and 2 (Figs 46-7) permit comparison of the Ternent scoring (1a and $2 \mathrm{a}$ ) with the original Stravinsky instrumentation ( $1 \mathrm{~b}$ and $2 \mathrm{~b}$ ). They demonstrate common ground where the brass, violins, cello/bass, and timpani are concerned. In fact, Ternent even adopted the short-score reduction in Stravinsky's vocal score as the basis for a piano part, adding ink annotations for his pianist, Billy Munn. ${ }^{48}$ At the upbeat to Fig. 46, for example, he writes: 'SOLO. Play with both hands. Top line only.' In the band manuscript (Example 2a) this line is apparently assigned to the xylophone, doubtless to showcase the band's virtuoso player, Harry Robbins. One notable difference is that Stravinsky's horns mutate into saxophones, so inflecting the sound slightly in a jazz-/dance-band direction, with Ternent himself playing the baritone part. Equally, the absence of the original oboe, cor anglais, bassoon, and viola results in a more homogeneous timbral palette, as well as an emphasis on the treble register. The main difference, to which I shall return, concerns the assignment of the vocal lines to the band instruments.

Secondly, there is a common pitch-time frame. Examples 1 and 2 show how, in this respect also, Stravinsky's original and Ternent's arrangement correspond closely. All pitches are carefully accounted for, albeit with some registral shifts, but no harmonic changes, interpolations, or cuts. Rhythmic changes are minimal, and specific articulations in the original score are skilfully mimicked: note, for instance, between Figs 44 and 45 the recreation of a cello pizzicato crotchet on the off-beats by means of a semiquaver followed by a dotted quaver rest on Ternent's baritone saxophone. Meanwhile Stravinsky's stress marks become more like acute accents, projected, for example, by the trombone (Fig. $45^{-3}$ and Fig. 45), while some slurs are removed. Small-scale dynamic differences, as at Fig. 46, are addressed below, but essentially this is a very literal transcription.

Thirdly, as evidenced by their reception, both versions of Mavra proved very difficult to bring off in performance, especially in the awkward environment of the Opéra. Stravinsky's Mavra had fared reasonably well in preview at the Hotel Continental, with the composer accompanying the voices at the piano during a lavish gala dinner put on by Diaghilev. However, its official première at the Opéra in 1922 with the Ballets russes had, in Stravinsky's own words, been deemed 'a downright failure'. ${ }^{49}$ On that occasion the fragile Mavra had been squeezed between the season's main ballet showpieces, Le sacre and Petrushka; the performance of the band-like ensemble that played for Mavra had also been mediocre. ${ }^{50}$ Stravinsky attributed the problems to such circumstantial factors: 'Alas! I was deeply disappointed by the disastrous surroundings in which my poor Mavra and little Renard found themselves. ${ }^{51}$ Others, however, including one critic whose testimony on both the Stravinsky

48 JHA, 599.

49 Stravinsky, An Autobiography, 103.

50 Taruskin refers to Mavra as having been 'accompanied by some kind of ungainly brass band conducted by Grzegorz Fitelberg' (Taruskin, Stravinsky and the Russian Traditions, vol. 2, p. 1592).

51 Stravinsky, An Autobiography, 103. 


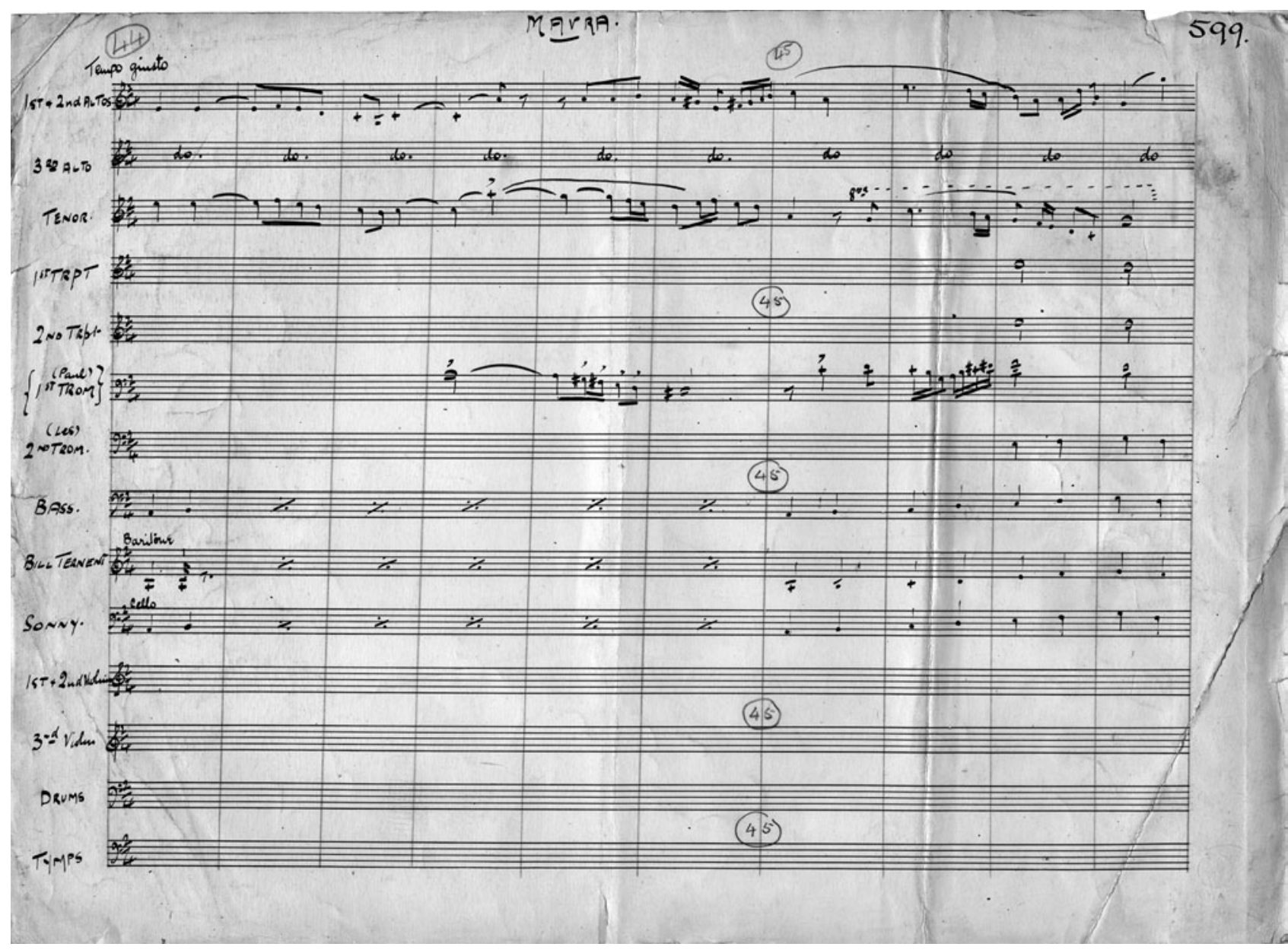

Example 1a Ternent's arrangement of Mavra, Figs 44-5. Reproduced by kind permission of Jack Hylton (Hylton's son) and the Jack Hylton Archive, Lancaster University. 

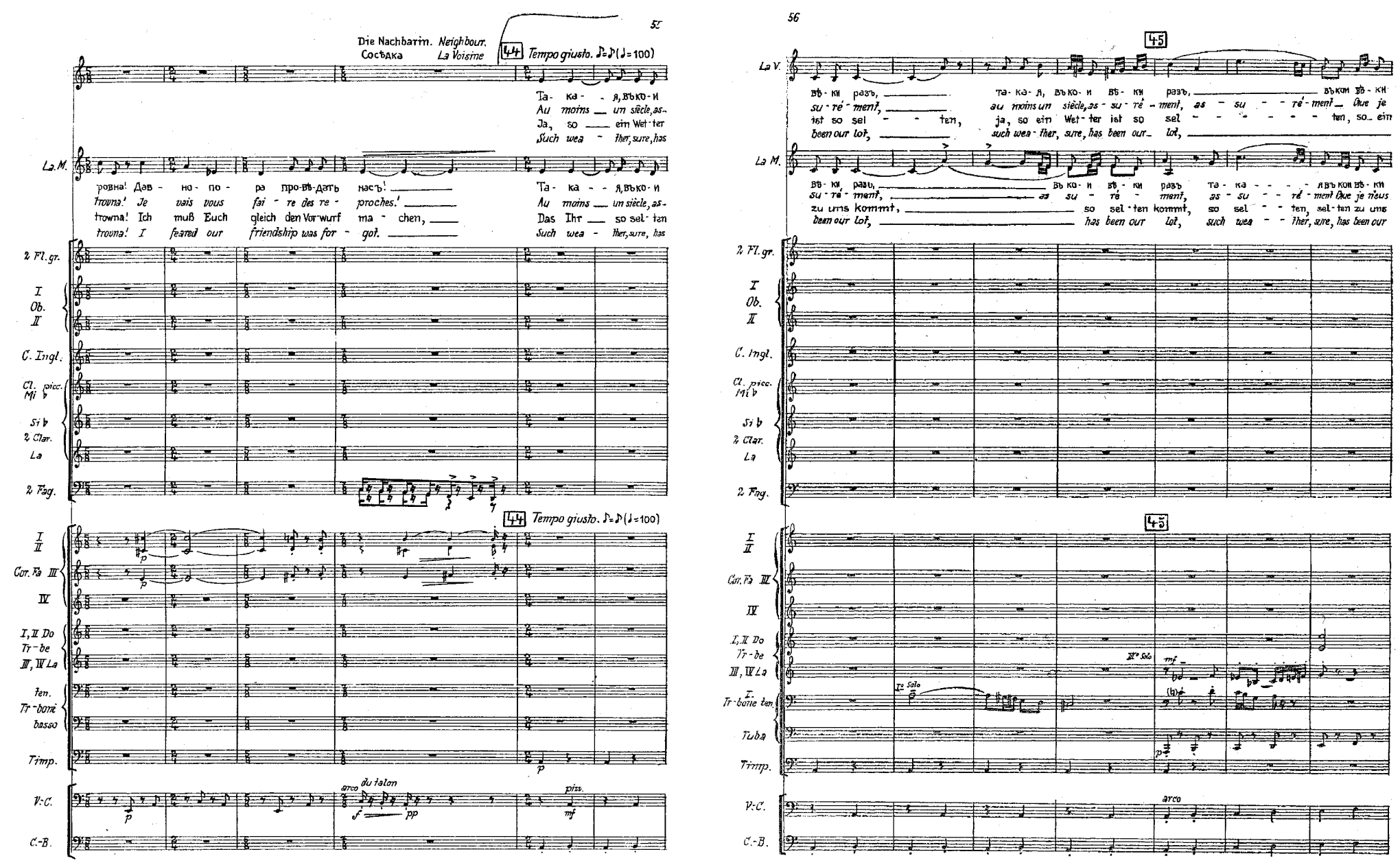

Example 1b Stravinsky, Mavra, full score, Figs 44-5. @ 1925 by Hawkes and Son (London) Ltd. Reproduced by permission of Boosey \& Hawkes Publishers Ltd. 


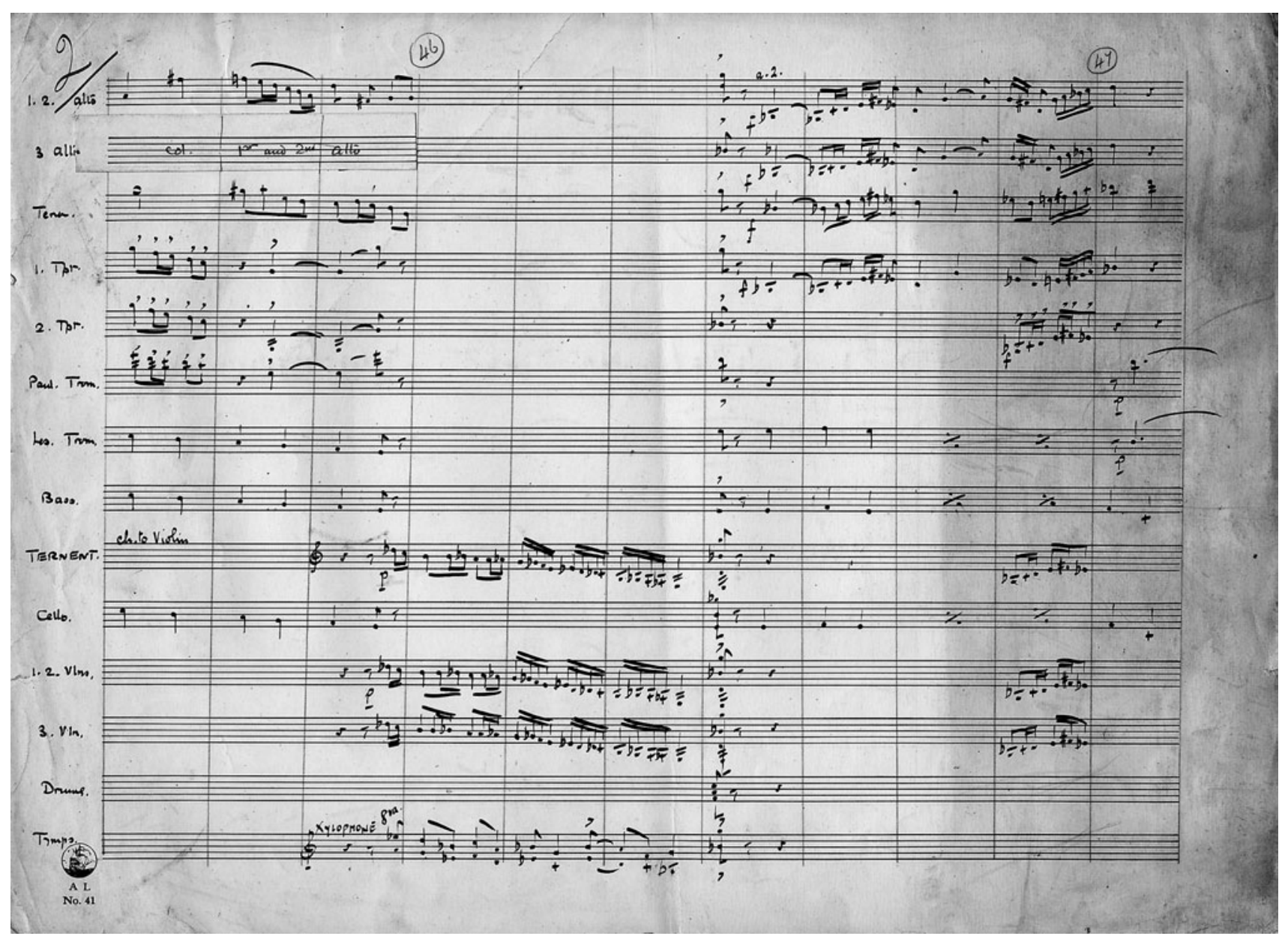

Example 2a Ternent's arrangement of Mavra, Figs 46-7. Reproduced by kind permission of Jack Hylton (Hylton's son) and the Jack Hylton Archive, Lancaster University. 


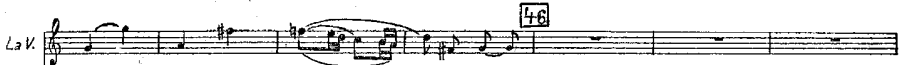

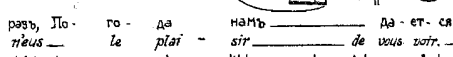

Net-ter, so ein Wet - - ter ist so set tert

LaM 20

pasb,
Pag

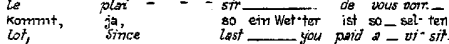

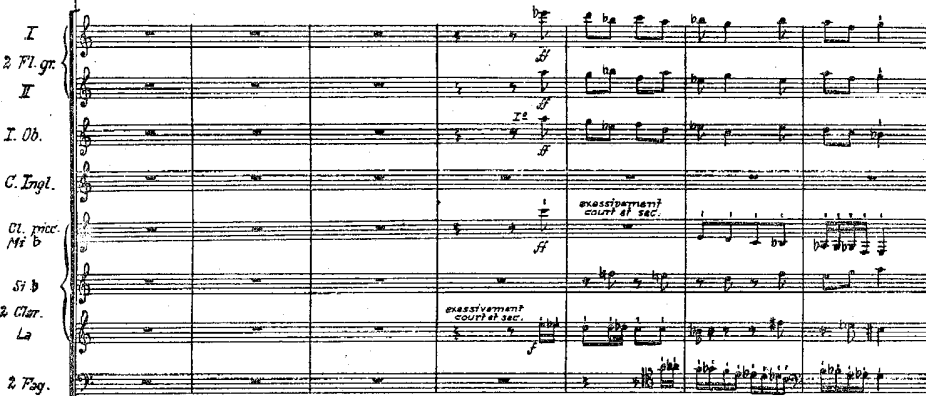

$V \cdot$ noI

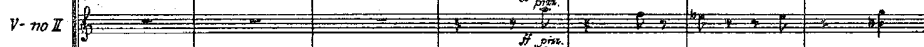

$v_{-l_{0}}$

$I, I, 10$

III, II

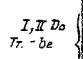

$\mathbb{I I}, \mathbb{H L}$

$\pi$-bone tent

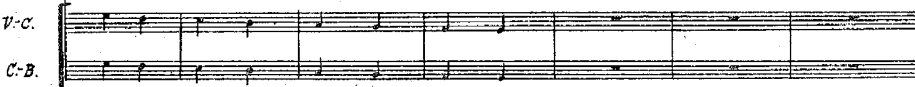

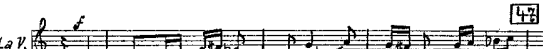

$1=$

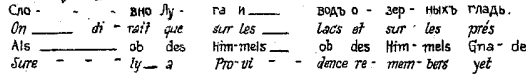

Lam

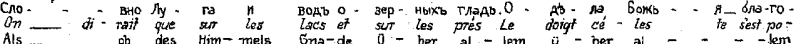

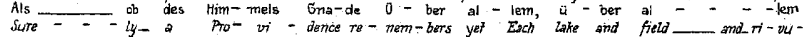

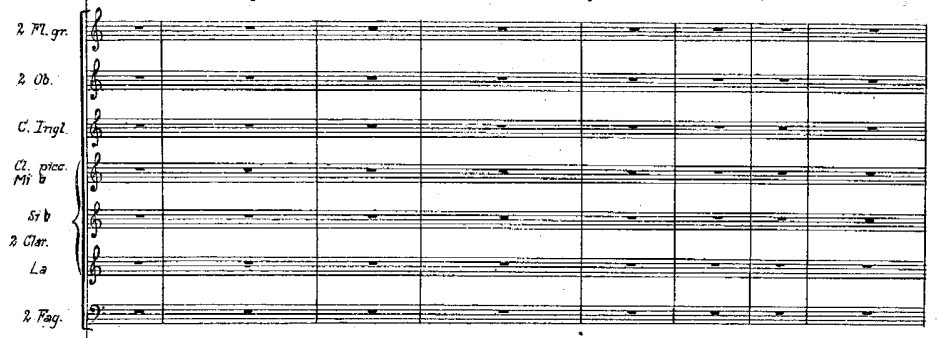

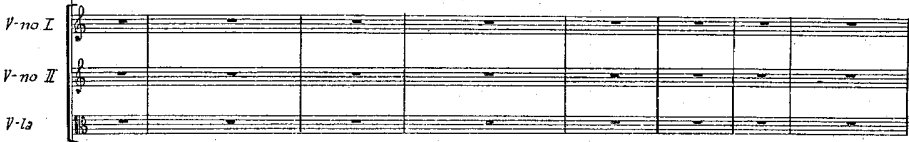

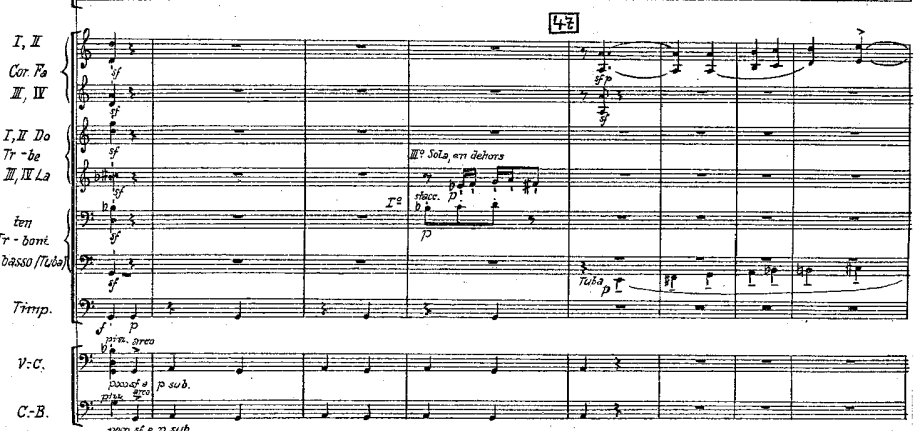

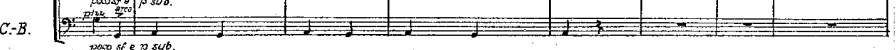

Example 2b Stravinsky, Mavra, full score, Figs 46-7. @ 1925 by Hawkes and Son (London) Ltd. Reproduced by permission of Boosey \& Hawkes Publishers Ltd. 
première and the later Hylton performance survives, placed some responsibility firmly back at Stravinsky's door. While extolling Stravinsky's rhythmic treatment, Vuillermoz strongly criticized the music's rather leaden quality and its melodic deficiency ('Strawinsky [...] manque terriblement d'invention mélodique'). ${ }^{52}$ Ironically, given the revisionist dimension within the raison-d'etre of Mavra, nineteenth-century melody may perhaps have gained the upper hand. The audience was shocked precisely because Mavra was not shocking: where was the pre-war iconoclast of Le sacre?

Similarly, Hylton's version fell down in performance, even in Ternent's more straightforward rethinking. While the band usually performed its material freely from memory, on this occasion it needed to read the arrangement, which must have had an impact on the spontaneity and sense of fun in the performance. Additionally, since it had been Ternent who had taken charge of teaching the arrangement to the band in rehearsal, the inexperienced Hylton had then lost his place while directing the score. Although the concert as a whole was well regarded, the reception of the Mavra performance, in both the French and the English press, was almost entirely negative - admittedly as much in reaction to the music itself as to its poor rendition:

An extract from Stravinsky's opera bouffe Mavra, arranged by William Ternent, was rather disappointing. The music was dull compared with the same composer's sparkling 'Petrouchka' or the new piquant suites for small orchestra. Neither Stravinsky nor Jack Hylton were $\left[\right.$ sic] in their element, and the work did not make a hit with the public. ${ }^{53}$

Even in its new incarnation, then, Mavra suffered from comparison with Petrushka on account of its apparent difficulty. ${ }^{54}$ Had Stravinsky anticipated such a reception or had he hoped that the work might fare better in its new guise? Did he underestimate the challenges of presenting Mavra in this way? While such questions will never be answered satisfactorily, the extent of common ground with the failed original is certainly significant in addressing the reasons for the Hylton version's lack of success.

\section{B Stravinsky and Hylton: 'complementation-contest'}

A second set of interactions, grouped as Interaction (B) in Figure 1, develops a conceptual spectrum from Cook's 'complementation' to actual 'contest' or, in Albright's language, a notion of increasing 'dissonance' between the original and the arrangements. ${ }^{55}$ The main subject matter concerns two further, crucial spectrums focused on the entwined parameters of genre and style: from jazz to classical and from light-hearted to serious. These spectrums do not necessarily operate in stereotypical tandem: in other words, jazz may not be lighthearted; classical music may not be serious. Despite the assumption of a little altered work-concept implicit in Stravinsky's expectation (quoted above) that 'the arrangement

52 Emile Vuillermoz, 'Mavra', Excelsior, 12 June 1922 (quoted in Taruskin, Stravinsky and the Russian Traditions, vol. 2, pp. 1596, 1597n).

53 ['The Concert-Goer'], 'Jazz at Paris Opera'.

54 This audience perception is corroborated by Vuillermoz, 'Jack Hylton à l'Opéra' (and by commentary in the New Herald [Paris], 19 February 1931).

55 Cook, Analysing Musical Multimedia, 99, 103; Albright, Untwisting the Serpent, 29. 
would conform to the original version', I argue for at least a moderate divergence between the two. And thus it is in Interaction (B) that I find potential for additional meanings to be 'actualized', 56 as a consequence of relating or 'blending' the differing versions.

Comparison of the respective scorings (shown in Table 1) suggests how each version of Mavra engages with the jazz-classical spectrum and, most especially where the Hylton arrangement(s) are concerned, the nature and degree of 'jazzing' that was involved. Essentially these orchestrational attributes, as outlined in Figure 1, reveal a complementary relationship. The left-hand side of Figure 1 identifies the Stravinsky sound as orchestral yet jazz-influenced, though, as Stravinsky himself suspected, his readings of ragtime (and jazz) must have sounded idiosyncratic to Americans ('very alien corn'). ${ }^{57}$ Taruskin, likewise, views this aspect of Mavra as rather tame ('pale pro forma stuff). ${ }^{58}$ While, as was noted above, Stravinsky had already completed his ragtime pieces, he still had some way to go to reach the Ebony Concerto.

On the right-hand side of Figure 1 Stravinsky's classical-'jazz' positioning is complemented by the 'jazz'-classical positioning of the Hyltonized dance-band sound. The latter favours sectional block scoring, with a doubling (and sweetening) of saxophones by violins. While it incorporates some jazz gestures, appropriately enough in the Gershwin-influenced era of symphonic jazz, it also exhibits symphonic tendencies, especially in Lucas's more literal and intricate arrangement. ${ }^{59}$ Jazz-like gestures may be perceived in Ternent's arrangement at various points. The very inclusion of players' names, for instance: 'Les' (the trombonist Leslie Carew) at Fig. 44, or 'Pogie' (the saxophonist Edward Pogson) at Fig. 91, is congruent with a jazz-band ethos whereby any score is merely an aid to performance by particular players. Example 3a may be regarded within this context. Following the punchy, accented trumpet/ trombone melody (Fig. $54^{-1}$ ), the listener is drawn towards an accompanying figure on the violins led by Ternent and marked 'Broad' and 'Sul D' (which assumes the vocal line of Mother), with the focus then shifted to a soloistic treatment of the first alto saxophone. These changing leads and hints of a jazz 'break' are suggestive of greater interpretative latitude or improvisational potential. Similar relations recur in a more spacious setting (Fig. 68), where bowed strings are again marked 'Broadly'; a forceful off-beat clash on foot cymbal then articulates the switch to a light pizzicato accompaniment, which backs a muted solo on the first trumpet (Fig. $68^{+4}$ ). Notable, too, are the 'open' versus 'hand-in bell' muted timbral effects for the second trombone (Fig. $54^{+2}$ ), which evoke a sense of jazz colour, these designations recurring across Figs 72-3.

56 See Cook, 'Theorizing Musical Meaning', 185, 186.

57 Stravinsky and Craft, Dialogues and a Diary, 87.

58 Taruskin, Stravinsky and the Russian Traditions, vol. 2, p. 1569. Taruskin also mentions another likely influence-cumsource in the shape of a popular music-hall show given in Paris in December 1920: the Chauve-souris (Bat Theatre of Moscow) (vol. 2, p. 1539).

59 Lucas left Hylton's band as a direct consequence of his rejected Mavra, but later realized his symphonic ambition as a composer of film scores. 
a

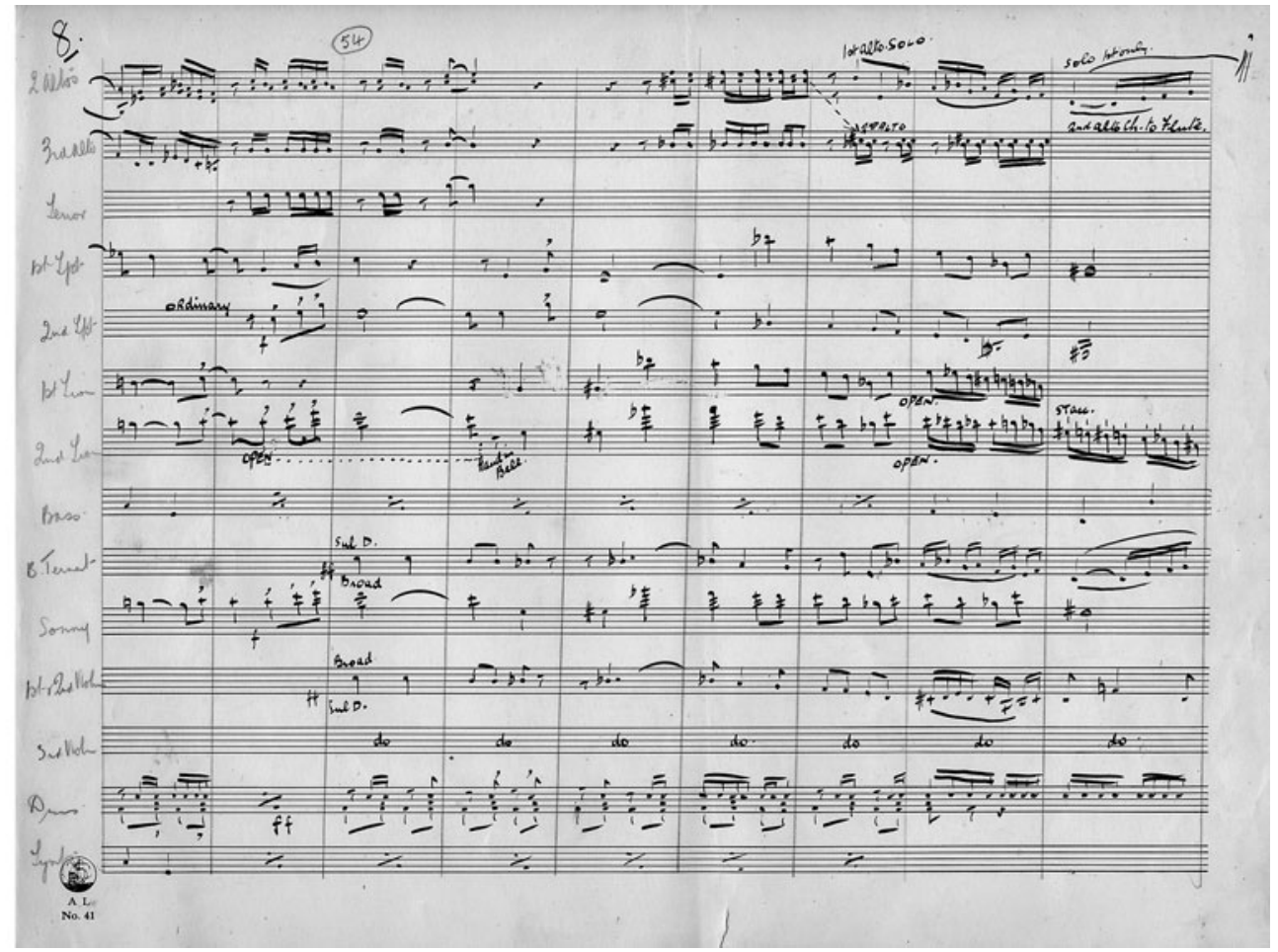

b

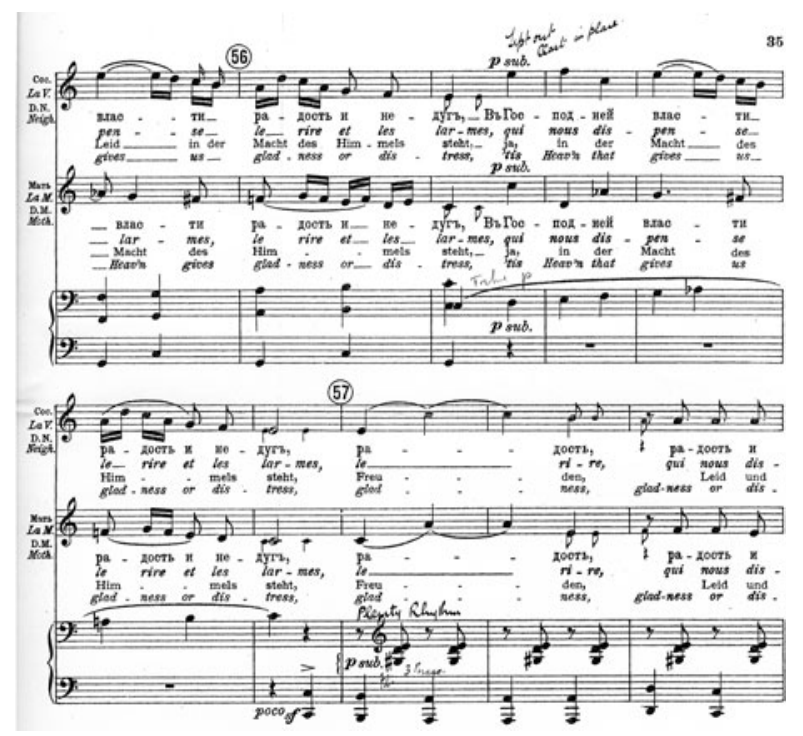

Example 3 'Jazz'/dance-band gestures: (a) Ternent's arrangement (Fig. 54). (b) Ternent's annotations on Stravinsky's piano reduction (Fig. 56).

Also richly suggestive are Ternent's dark-blue ink and pencil annotations upon the published vocal score received from Stravinsky; see Example $3 \mathrm{~b} .{ }^{60}$ The frequent instrumental 
changes so typical of early jazz are evident in markings such as ' $\operatorname{Tr}[\mathrm{um}] \mathrm{p}$ [e]t out, Clar[ine]t in place' (Fig. $56^{+2}$ ): Ternent especially, almost a one-man band, was famed for his skill in switching instruments deftly. Additionally, the accompaniment designation of 'Plenty rhythm' (Fig. 57), with its African-American implications, pushes the jazz identity at least a little further. On the other hand, the portion of music around Fig. 54 was already part of Stravinsky's light-hearted 'Gossip Duet', with its polka-like qualities. ${ }^{61}$ Jazz/dance-band gestures were embedded, as when, a little later on (Fig. $74^{-4}$; Example 4a), Stravinsky alerts his second horn player to a big 'Solo' moment and urges him to 'Make an attractive, full, and round sound' ('Donnez un joli son plein et rond'). Straight after this (Fig. 74) the pizzicato pitches of the cellist are to be played 'by leaving each note to vibrate' ('en laissant vibrer chaque note'), thus emulating a resonant jazz bass. Stravinsky also stipulates glissandos for his trombones (Fig. 87, Fig. $88^{+2}$; Example 4b) and marks his solo trumpets 'assez dehors' (Fig. $88^{-1}$ ). Curiously, these jazzed details are removed from Ternent's arrangement, which effectively 'cleans up' the sound - a matter to which I shall return below.

With respect to the second element of 'complementation-contest' listed in Figure 1 - that concerning the opera buffa genre and the associated spectrum from the light-hearted to the serious - significant differences between Stravinsky and Hylton are revealed. Stravinsky struggled to find a light, witty touch befitting opera buffa, thus somewhat vindicating Vuillermoz's accusations, discussed above, about the lack of melodic inspiration. Despite some 'spoofing' identified by Taruskin, ${ }^{62}$ Mavra is, paradoxically, complex, quite abstruse, and ironic (yet also sincere), with a lingering heaviness. Moreover, it is steeped in narrative, dramatic, and historicized meanings (the latter symbolized by Stravinsky's dedication of the score: 'A la mémoire de Pouchkine, Glinka et Tschaïkovsky').

In Hylton's version, on the other hand, extra-musical meanings were concealed, or disguised like Mavra him/herself, certainly for the audience of jazz- or dance-band rather than opera fans who flocked to hear the work that night. ${ }^{63}$ Although Hylton's band was used to presenting operetta selections by Lehár and Offenbach, this offering was not in the usual mould. It was neither opera nor buffa, even if, in the supportive opinion of one contemporary critic, 'as a piece of music it stands securely on its own feet without the dramatic context from which it is taken and without the words or the differentiation of the dramatis personae. ${ }^{64}$ But, as mentioned above, Hylton then struggled on the podium, evidently feeling some discomfort, while his band was seemingly cautious and on edge. So while there was no intentional dramatic meaning, what unfolded on stage was an unplanned drama, characterized by Munn as 'a horrifying nightmare'. ${ }^{65}$ In Example 4c Hylton's battle may be seen as symbolized by the last page of Ternent's arrangement (Figs 91-2): in the spirit of hardpressed copyists from time immemorial is inscribed a heart-felt 'Thank God!', signifying the end of his own labours against the clock, just weeks before the Opéra performance.

61 Taruskin, Stravinsky and the Russian Traditions, vol. 2, p. 1569.

62 Taruskin, Stravinsky and the Russian Traditions, vol. 2, pp. 1550, 1574.

63 See Vuillermoz, 'Jack Hylton à l'Opéra'.

64 [Writer unknown], 'Stravinsky and Jack Hylton'.

65 [Writer unknown], 'Jack's Mood', Le carnet de la semaine, 1 March 1931; quoted in Faint, 'Jack Hylton', 74. 


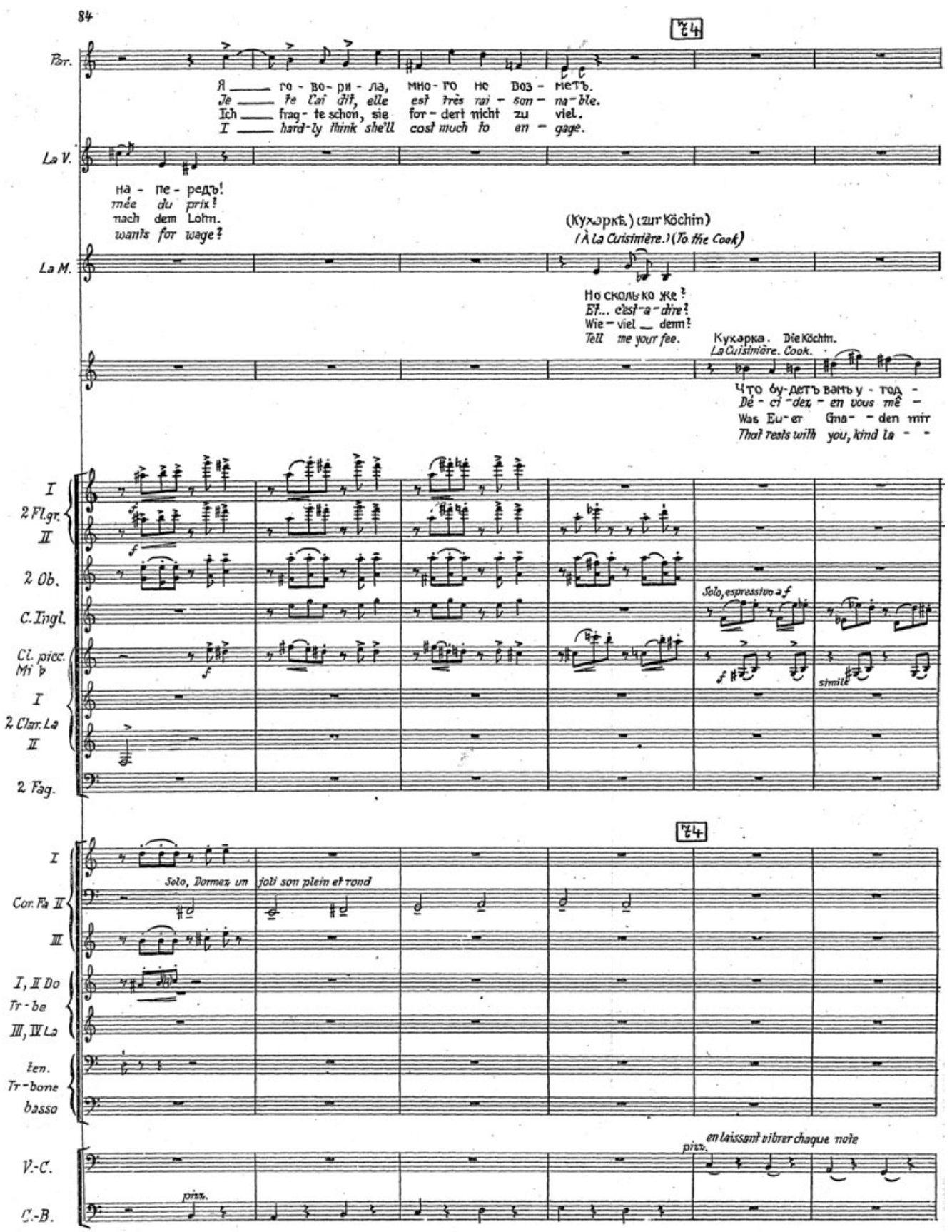

Example 4a Stravinsky’s original (Fig. 74): 'jazz'/dance-band gestures.

In this way Stravinsky's Mavra, a work that already embodied a kind of faux sentimentality, was presented in all seriousness by an anxious dance band, whose audience associated Hylton with levity and was therefore bemused and bored. Ironically, although Hylton's 
87

38

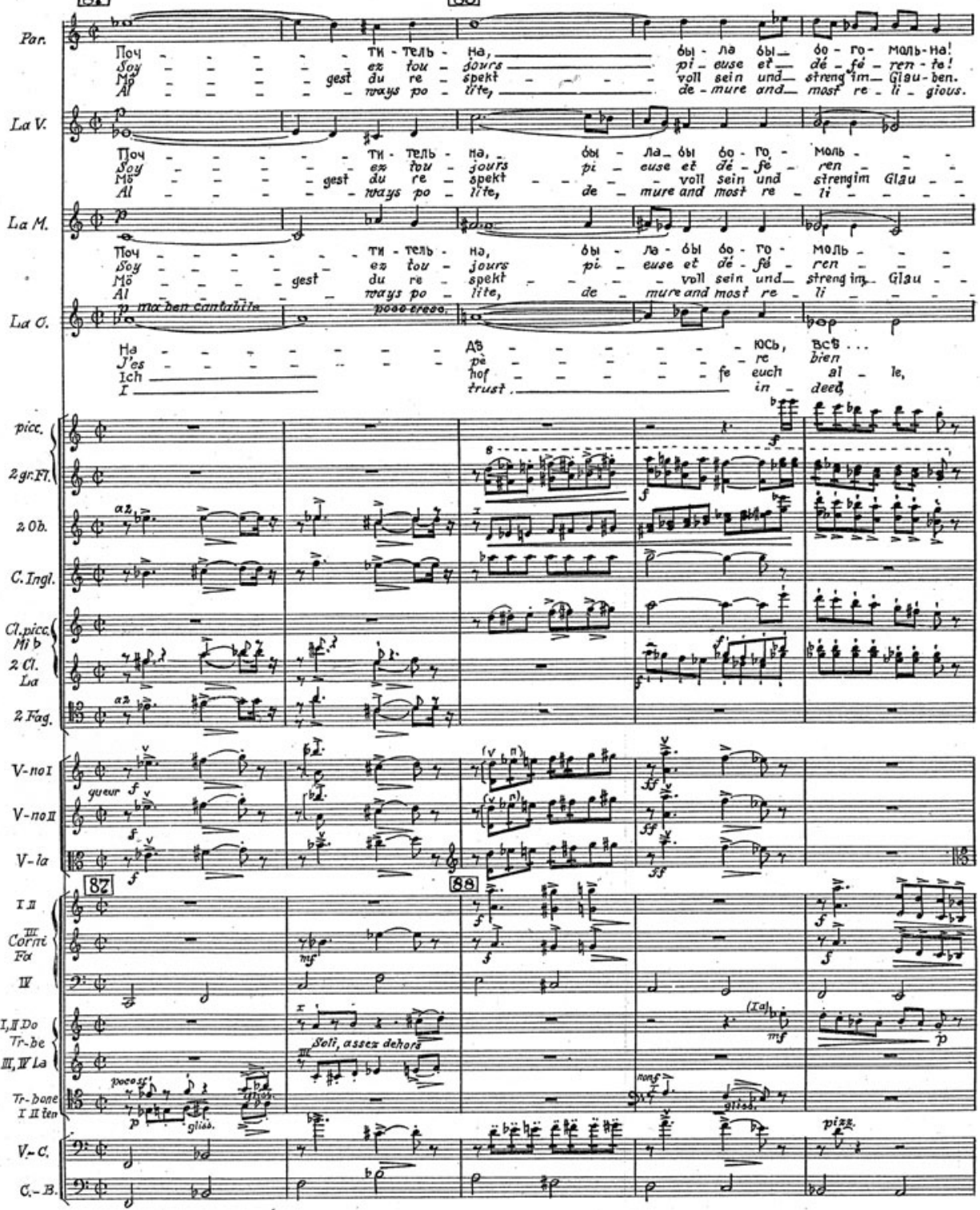

Example 4b Stravinsky's original (Figs 87-8): 'jazz'/dance-band gestures.

Mavra was no longer opera, his band's much publicized infiltration of jazz into the sacrosanct Opéra had taken the form of spoof opera - an aspect of the event that was parodied the following month by Clément Vautel in the satirical publication Cyrano:

VERDI: What's that I hear? What is that awful uproar? [...]

GOUNOD: It's the Sabbath ... Mephisto is at the pulpit.

SAINT-SAËNS: Do you not find that it's rather like Reyer? 


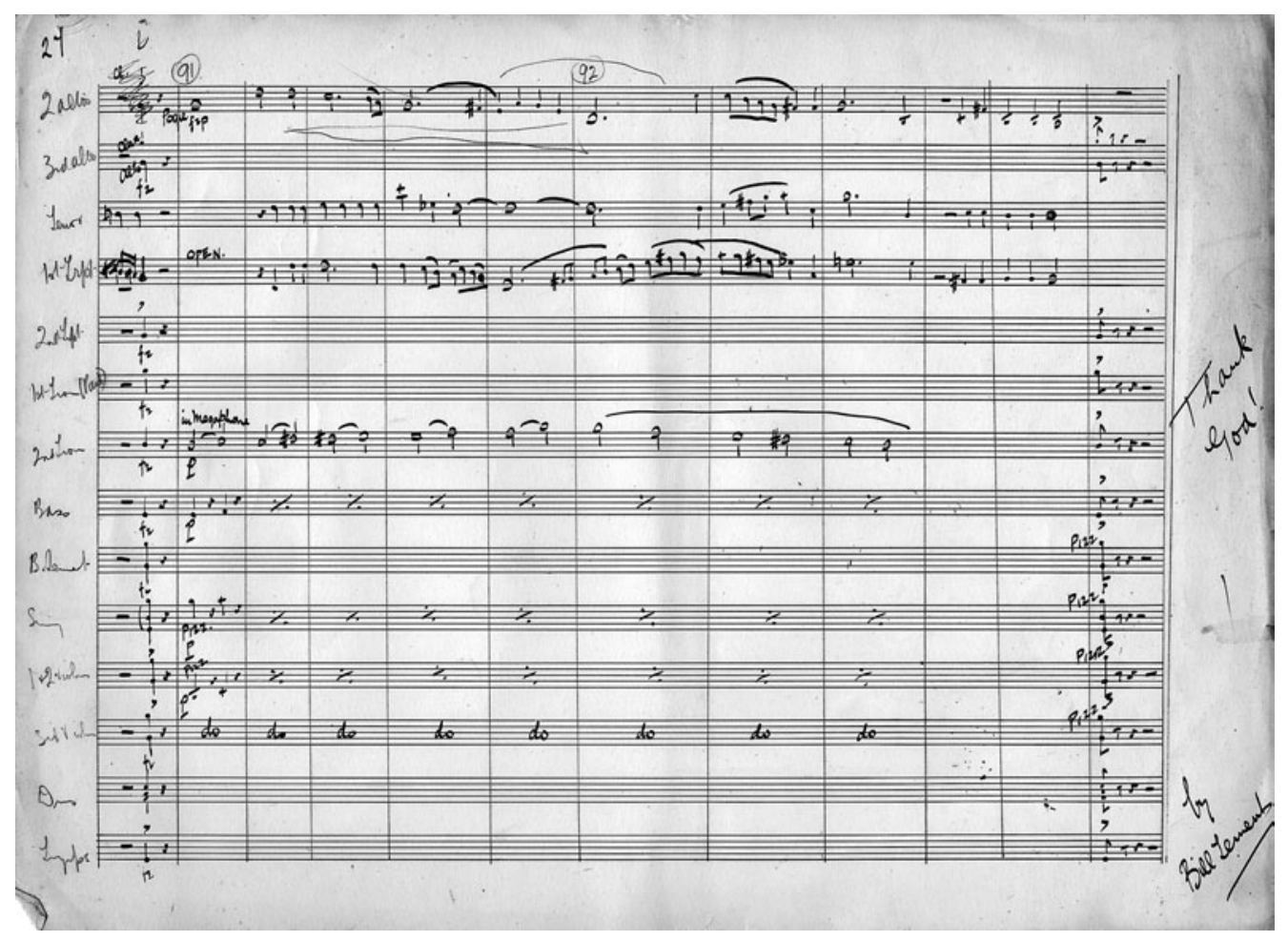

Example 4c Ternent's final page (Figs 91-2).

MASSENET: My dear Saint-Saëns, is it yours, this delightful music here?

BIZET: Gentlemen, they profane the temple ... It's sacrilege! ${ }^{66}$

In terms of the conceptual blending of this opera/non-opera category in the original and the arranged versions of the work, the effect is of Cook's 'contest', embodying conflict and 'contradiction' ${ }^{67}$ or, to recall Leroi's judgement quoted at the opening of this article, 'la confusion'.

Pursuit of the fundamental notion of neoclassicism develops further notable differences, as outlined in Figure 1. Stravinsky's Mavra undoubtedly has such a foundation, yet, surprisingly perhaps, it might be argued that in various respects Ternent's arrangement offers a heightened neoclassicism. While Stravinsky's original combines voices and instruments, Hylton's arrangements reduce it to a purely instrumental medium. Paradoxically, this process of isolating parts of stage works for instrumental treatment was very much a neoclassical trait, practised by Stravinsky in his own suites, such as those from Pulcinella or

66 Vautel, 'Le jazz à l'Opéra':

VERDI: Qu'entends-je? Quel est ce vacarme affreux? [...]

GOUNOD: C'est le sabbat [...] Méphisto est au pupitre.

SAINT-SAËNS: Vous ne trouvez pas que cela ressemble à du Reyer?

MASSENET: Mon cher Saint-Saëns, c'est de vous, cette délicieuse musique-là?

BIZET: Messieurs, on profane le temple ... C’est un sacrilège!

67 Cook, Analysing Musical Multimedia, 99, 102-3. 
L'histoire du soldat. Interestingly, Lucas too termed his rendition a suite. In Ternent's reading Stravinsky's vocal material is generally, though not invariably, adopted by the saxophones, resulting in a certain 'disembodiment' - a literal one, where the singers are concerned. On Ternent's predominantly black-inked manuscript can be found pencilled annotations (Fig. 72): 'Neighbour' (alto saxophone), 'Mother' (tenor saxophone), and 'Par.' (first trumpet), which are labelled carefully to ensure that the content of the vocal lines had been properly accounted for.

Although, theoretically, all intertextual and related meanings had not been lost, ${ }^{68}$ they had, as was pointed out above, been rendered inaccessible for the audience of first-time Stravinsky listeners at its only performance. In this sense of apparent dépouillement - a stripped state - Mavra had effectively been fashioned into 'absolute' music. In fact Hylton's band had its own tradition of creating both vocal and instrumental versions of the same song: within its contemporary French repertory, for instance, parallel numbers were created from Maurice Chevalier's films and from José Padilla's chansons 'Ça c'est Paris' and 'Fleurs d'amour'. ${ }^{69}$ Here the practice worked, however, because, unlike with Mavra, the audience could readily identify with the tune, lyrics, or message, and could effectively sing along.

Furthermore, in his dynamic and formal treatment Stravinsky had subverted expectations by fashioning a fortissimo linking passage on clarinets and bassoon (Fig. 46; Example $2 \mathrm{~b}$ again) into a new portion with lower strings and brass marked piano subito (Fig. $46^{+4}$ ) to avoid overpowering the vocal entry. Conversely, Ternent's more conventional rereading employs a piano transition on violins (Fig. 46; Example 2a) to lead into a forte saxophone phrase (Fig. $46^{+4}$ ), thus emphasizing the formal, classical architecture. Similarly, à propos Figs 74 and 87-8, Ternent's cleaning up of Stravinsky's sounds may be recalled, while in the final bars (Fig. 91; Example 4c) the instruction to the second horn to play 'in megaphone' creates an inevitable reminder of Walton's neoclassical tour de force, Façade.

A final consideration where neoclassicism is concerned is the contrast (highlighted in Figure 1) between the durations of the full one-act opera and a six-minute extract ${ }^{70}$ that has been physically detached from the whole - albeit at the composer's probable instigation. Since those dance-band fans at the Opéra would not generally have known Mavra beyond the performed extract, there was an increased pressure upon the modified work-concept to account somehow for the original objectives in a fraction of the time and to function as a kind of metonym - a tough assignment. A consequence, consistent with neoclassical inclinations to reorder material (e.g. Ravel's orchestration of Le tombeau de Couperin, which ends with the Rigaudon, the fourth of an original six movements), is that the original middle becomes an ending - or rather a non-ending, since Fig. $92^{+6}$ finishes with a whimper rather than a roar.

So, from the vantage-point of conceptual blending, the Hylton/Ternent version gives rise to new emergent meanings in the spirit of Stravinsky's own recomposition projects.

68 For more on this fascinating topic see Chua, Absolute Music.

69 See Mawer, “"Parisomania”?', 290-93.

70 Limited as it may seem, a duration of six minutes was unusually long for a Hylton band number. It would, for instance, have required both sides of a ten-inch $78 \mathrm{rpm}$ disc recording, with the resulting side-break. 
But, ironically, while purporting to be a 'jazz'-oriented arrangement, and despite a contemporary press assertion that 'The excerpt has been jazzed 100 per cent,, ${ }^{71}$ it outdoes its source in a (neo)classical direction through creating an instrumental miniature. This further artificial distillation now involves, theoretically at least, a new parodic layering of quotation (and cultural association): Hylton quoting Stravinsky quoting Glinka, among others. $^{72}$

\section{Further meanings and conclusion}

To refer back to Leroi's review, Mavra certainly involves the international 'mixing' if not actual 'muddling' ('la confusion') of styles and genres. But ultimately the problem is not stylistic mixture as such: after all, there are many successful examples of 'jazzing' the classics (and indeed of 'classicizing' jazz) by Ellington, Whiteman, Payne, Hylton himself, and others. The issue is a lack of balance between the various elements: in terms of a recipe, the wrong proportions and, possibly, too many ingredients. Interpreted and performed in stressful circumstances, the Hylton band's Mavra was, I argue, too much an act of classical homage and, crucially, to reuse that journalistic tag, insufficiently 'jazzique'. In my chosen methodological terms the arrangement(s) generated insufficient 'contest' or 'dissonance' à propos the treatment of jazz in relation to Stravinsky's original.

Hylton felt uncomfortable and his players were restricted, partly because Ternent's arrangement was itself constrained, conceptually and literally, by a shortage of time. Stravinsky's distancing of himself from the project (which effectively made it into a homage to him by the Hylton band, though his original proposal to Hylton had implied the reverse) resulted in a 'confusion' or fuzziness of purpose, yet the product was still meant to be entertaining. Whatever his contrariness, there was more than a grain of truth in Stravinsky's later assertion that 'the musicians tried to play the music "strictly". Mr. Hylton had merely transcribed the music for his combination of instruments. ${ }^{73}$

But Stravinsky should have been careful in pointing the finger: at least some of the problems that Hylton encountered were inherent in the original Mavra. It would have been much easier if the two musicians had started elsewhere, for instance with the new composition that, tantalizingly, Stravinsky seemed initially to have proposed. After all, Mavra is deceptively complex, rather diffuse, serious, and lacking in mass appeal - especially as regards a good tune, so important to the success of Hylton's band. Stravinsky's and Kochno's 'in-jokes', parodying opera buffa and nineteenth-century literature, were subtle and probably only really appreciable by a Russian audience.

To have stood any chance of success from such a problematic starting-point, Ternent's arrangement should perhaps have taken more risks. It should have been more improvisatory, furthering the approach adopted, for instance, in those embryonic soloistic lines found in

71 ['By our Special Correspondent'], 'A Gramophone Rehearsal, Stravinsky and Jack Hylton'. It is not clear to which arrangement the comment applies, but Lucas's version was in any case even less 'jazzed'.

72 For more on this topic see again Metzer, Quotation and Cultural Meaning.

73 Stravinsky and Craft, Expositions and Developments, 82n. 
Example 3: more colourful and theatrical, less reverent - consistent, in fact, with Hylton's usual light-hearted fare. Crucially, it required performance in a manner that highlighted these qualities. After all, a Times critic, in an article of 29 January 1931, who heard a reasonable rehearsal by Hylton's band in the Small Queen's Hall studio, concluded that Stravinsky should be pleased by 'this experiment in rescoring'.

There is always a discernible gap in such repertory between the score, as a fairly crude indicator of the intended effect (the means), and the performance (the end). It would definitely be worth testing out in performance whether Ternent's arrangement could be facilitated by the judicious incorporation of glissandos, pitch-bending, improvisatory melodic decoration, and cadenza-like 'breaks', furthering the spirit of Figs 54 and 68 and enlivening the textural build-up to the climax (Figs 75-86). While Ternent succeeded in adding some 'edge' to the sound with his second trumpet and trombones $\left(f f\right.$ and $f z$ : Fig. $\left.86^{+2}\right)$, since he was spared Stravinsky's worry of covering the voices, the music as notated still does not quite 'let go'. Although a diffident performance clearly alienated the dance-band enthusiasts in Paris that night, a spontaneous, exciting, and 'dissonant' rendition on the basis suggested above might potentially have brought a new audience to Stravinsky's music (and might still).

One might also infer wider symbolic meaning from the event. The Mavra episode caused both Stravinsky and, especially, Hylton to be understood as capable of technical flaws and errors of judgement. For Stravinsky it was a very painful experience. ${ }^{74}$ The performance of February 1931 no doubt carried a strong sense of history being repeated, thus exacerbating the wound of 1922 - hence not only his vigorous rewriting of that history but also his definitive setting-down of the work on the Pleyela mechanical piano, as if in an attempt to prevent future misinterpretation. ${ }^{75}$ Nonetheless, the Hylton/Stravinsky Mavra seems to have got the composer thinking of a version of Petrushka to be scored for a similar type of 'popular orchestra'. Moreover, it was Stravinsky's Mavra that acted, symbolically, as a catalyst for much of his later output: 'it [Mavra] marked a turning point in the evolution of my musical thought ${ }^{76}$ and was a work which, in 1947, he would revisit and revise.

By contrast, Hylton had reached the peak of his career, enjoying overall success. His concert at the Opéra, broadcast by Radio-Paris, was not only sold out but also overran by almost an hour because of popular demand. But Mavra exposed a chink in his armour: although he had come an impressive distance through his own efforts, it made painfully public his musical limitations. More seriously, since he had previously been so astute, it revealed an entrepreneurial misjudgement. Tellingly, it prefigured other miscalculations: his decision to reduce his band's stage spectacle in the early 1930s and his generally unsuccessful later move into television, which he subsequently corrected by returning to his familiar theatrical world. Although he was yet to receive the Légion d'honneur and yet to introduce to Britain the legendary Duke and Coleman Hawkins in 1933-4, the small-scale failure of

74 Taruskin, Stravinsky, vol. 2, p. 1591.

75 Stravinsky, An Autobiography, 101.

76 Stravinsky, An Autobiography, 103. 
Mavra, it can be argued, signalled a larger decline, influenced by factors beyond his control: the demise of music-hall entertainment amid changing leisure pursuits and the spectre of unemployment in the wake of recession.

The survival of these two arrangements of Mavra for Jack Hylton and his Orchestra (the official title of Hylton's band at this time) does not enable us to recapture all the qualities of the performance at the Paris Opéra in February 1931. Nonetheless, closer examination of these archival sources illuminates some of the challenges of crossing stylistic and genre boundaries - the mixing ('confusion') of which Leroi spoke pejoratively but which the language of conceptual blending allows us to model a good deal more objectively and even-handedly. Conceptual blending is not without its critics: those who wonder whether the diagrammatic method achieves any more than prose alone, or whether notions of metaphorical space raise as many questions as answers. ${ }^{77}$ Is 'running the blend' so different from just comparing and contrasting the two entities directly? Visually, might the layout create a false neatness and a sense of sharply delineated boundaries such that hermeneutic strategy, or cognitive perception, comes to masquerade as 'fact'? These are legitimate questions, and ones that have led me here to restrict my use of the model to a fluid invocation of its main principles. Nonetheless, a systematic analysis of the conceptual blend resulting from the Hylton-Stravinsky encounter opens up interesting possibilities of complementation as well as contest - not least the notion that Hylton's version might outdo the original in terms of the neoclassical ideal of dépouillement. That the Hylton-Stravinsky experiment was regarded almost uniformly as a failure should not be allowed to efface its historical importance. Indeed, this problematic encounter might go some way towards explaining why Europe did not enjoy a collaborative product like that more famous 'Experiment in Modern Music', 78 the Gershwin/Whiteman Rhapsody in Blue - which, while far from flawless, yet remains among the most enduring examples of 'jazz'-classical fusion.

\section{Bibliography of materials in the Jack Hylton Archive, Lancaster University}

Manuscript band arrangements (file no. 599), including Leighton Lucas, Mavra (Figs 44-92; 97-112), and William Ternent, Mavra (Figs 44-91; signed).

Stravinsky, Igor. Mavra. Berlin and London: Edition Russe de Musique (Russischer Musikverlag [Boosey \& Hawkes]), 1925 (3 scores: 1 vocal score signed by Stravinsky and annotated by William Ternent, 1 vocal score marked 'Jack', and 1 orchestral score).

Programme JHPR9701267. 'Théâtre National de l’Opéra' (17 February 1931).

Various volumes of Jack Hylton [Press] Cuttings (JHCU):

['By our Special Correspondent']. 'A Gramophone Rehearsal, Stravinsky and Hylton'. Daily Telegraph, 29 January 1931.

Hylton, Jack. 'Taking or Inflicting Pains' (interview with Perceval Graves). Melody Maker (May 1928), 513-14.

-. 'Jazz Music: Is the Expression Objectionable?' Midland Daily Telegraph, 6 March 1931.

—. 'Naissance et vie du jazz'. Le courrier musical et théâtral, 15 March 1932.

_. 'Jazz! The Music of the People'. Woman's World supplement, 7 October 1934.

Leroi, Pierre. 'Jack Hylton à l'Opéra'. L'édition musicale vivante 37 (February 1931), 12-13.

Lucas, Leighton. 'What I Hate in "Jazz"'. Melody Maker \& British Metronome (February 1928), 137-9.

77 See Ritchie, 'Lost in "Conceptual Space”.

78 'An Experiment in Modern Music' was the programme title of Whiteman's celebrated concert given in the Aeolian Hall, New York, on 12 February 1924, featuring the first performance of the Rhapsody. For a reproduction of the poster see Thomas A. DeLong, Pops: Paul Whiteman, plate facing 80. 
Lucas, Norman. 'Jack Hylton and Stravinsky: a Jazz Symphony'. The Era, 4 January 1931.

Martin, Louis-Léon. 'Jack Hylton and His Boys'. Paris-midi, 6 January 1928.

—. 'Théâtre des Champs-Elysées: Jack Hylton and His Boys'. Paris-midi, 19 October 1930.

['The Concert-Goer']. 'Jazz at Paris Opera; Jack Hylton Makes History; Success of Last Night's Concert', Continental Daily Mail, 18 February 1931.

Vautel, Clément. 'Le jazz à l’Opéra'. Cyrano 350 (1 March 1931).

Ventura, Ray. 'Le triomphe du jazz: Jack Hylton à l’Opéra'. Jazz-tango 2/6 (1 March 1931), n. p.

Vuillermoz, Emile. 'La musique: Jack Hylton et ses "boys” au Théâtre des Champs-Elysées. Les concerts'. Excelsior, 7 April 1930.

—_. 'Jack Hylton à l'Opéra'. Excelsior, 21 February 1931.

__. 'La musique, les concerts'. Excelsior, 23 February 1931.

—_. 'Jack Hylton à l'Opéra'. Excelsior, 24 February 1931.

[Writer unknown]. “'Jazz Only in its Infancy”: Mr Jack Hylton replies to Mr Gillespie’. Nottinghamshire Guardian, 4 February 1927.

[Writer unknown]. 'Jack Hylton's 9,000 Mile Tour'. Daily Sketch, 29 May 1930.

[Writer unknown]. 'Jack Hylton's Jazz Guiding Stravinsky'. Variety, 4 June 1930.

[Writer unknown]. 'Stravinsky and Jack Hylton'. The Times, 29 January 1931.

[Writer unknown]. 'Stravinsky et Jack Hylton'. Je suis partout, 14 February 1931.

[Writer unknown]. 'Jack Hylton à l'Opéra', Le monde musical, 28 February 1931.

\section{Bibliography}

Albright, Daniel. Untwisting the Serpent: Modernism in Music, Literature, and Other Arts. Chicago: University of Chicago Press, 2000.

Chua, Daniel K. L. Absolute Music and the Construction of Meaning. Cambridge: Cambridge University Press, 1999.

Cook, Nicholas. Analysing Musical Multimedia. Oxford: Clarendon Press, 1998.

- 'Theorizing Musical Meaning'. Music Theory Spectrum 23/2 (2001), 170-95.

Cooke, Mervyn. 'Jazz Among the Classics, and the Case of Duke Ellington', in The Cambridge Companion to Jazz, ed. Mervyn Cooke and David Horn. Cambridge: Cambridge University Press, 2002. 153-73.

Craft, Robert, ed. Stravinsky: Selected Correspondence. 3 vols. London: Faber, 1982-5.

DeLong, Thomas A. Pops: Paul Whiteman, King of Jazz. Piscataway, NJ: New Century Publishers, 1983.

Faint, Peter. 'Jack Hylton: His Life in Music'. MPhil. diss., Lancaster University, 1998.

Fauconnier, Gilles, and Mark Turner. The Way We Think: Conceptual Blending and the Mind's Hidden Complexities. New York: Basic Books, 2002.

Fawcett, Liz. 'The Jack Hylton Archive at Lancaster University'. Brio 41/1 (2004), 32-6.

Fry, Andy M. "'De la musique nègre au jazz français”: African-American Music and Musicians in Inter-War France'. DPhil. diss., University of Oxford, 2003.

Jackson, Jeffrey H. Making Jazz French: Music and Modern Life in Interwar Paris. Durham, NC, and London: Duke University Press, 2003.

Klein, Jean-Claude, and J. Barrie Jones. 'Borrowing, Syncretism, Hybridisation: the Parisian Revue of the 1920s'. Popular Music 5 (1985), 175-87.

Lakoff, George, and Mark Johnson. Metaphors We Live By, 2nd edn. Chicago: University of Chicago Press, [1980] 2003.

Mawer, Deborah. 'Balanchine's La valse: Meanings and Implications for Ravel Studies'. Opera Quarterly 22/1 (2006), 90-116.

- "Parisomania"? Jack Hylton and the French Connection'. Journal of the Royal Musical Association 133/2 (2008), 270-317.

Metzer, David. Quotation and Cultural Meaning in Twentieth-Century Music. Cambridge: Cambridge University Press, 2003.

Nattiez, Jean-Jacques. Music and Discourse: towards a Semiology of Music, trans. Carolyn Abbate. Princeton: Princeton University Press, 1990.

Nott, James. Music for the People: Popular Music and Dance in Interwar Britain. New York: Oxford University Press, 2002.

Parsonage, Catherine. The Evolution of Jazz in Britain, 1880-1935. Aldershot: Ashgate, 2005.

Prunières, Henry. 'Jack Hylton'. La revue musicale 104 (1930), 462-3.

Ritchie, L. David. 'Lost in “Conceptual Space”: Metaphors of Conceptual Integration'. Metaphor and Symbol 19 (2004), 31-50. 
Rust, Brian, and Sandy Forbes. British Dance Bands on Record, 1911 to 1945, and Supplement, 2nd, rev., edn. Harrow: General Gramophone Publications, 1989.

Stravinsky, Igor. An Autobiography. London: Calder \& Boyars, 1975. , and Robert Craft. Dialogues and a Diary. London: Faber, 1968. , and Robert Craft. Expositions and Developments. London: Faber, 1968.

Taruskin, Richard. Stravinsky and the Russian Traditions: a Biography of the Works Through Mavra, 2 vols. Oxford: Oxford University Press, 1996.

Walsh, Stephen. The Music of Stravinsky. Oxford: Clarendon Press, 1988.

Zbikowski, Lawrence M. Conceptualizing Music: Cognitive Structure, Theory, and Analysis. Oxford: Oxford University Press, 2002. 